\title{
A Teaching System for Core Competence-based ITO Talents Training
}

\author{
Shiping Ye, Binbin Zhou, and Chaoxiang Chen
}

College of Information Science \& Technology, Zhejiang Shuren University, Hangzhou, China

email: zjsruysp@163.com

Keywords: Information Technology Outsourcing (ITO); Curriculum System; Practice System

\begin{abstract}
In this paper, we analyze the core competencies of the talents requirements of information technology outsourcing (ITO). We also discuss contradictions between traditional teaching in computer software-related specialties (CSS) and requirements for ITO talents. According to the top-level design, we re-construct a theoretical and practical courses system consists of general education, basic specialty courses and specialty courses, taking the knowledge and abilities of ITO talents required as objectives. And then, we propose suggestions for curriculum reform, curriculum construction and corresponding teaching staff construction. Finally, we prove the effectiveness of this reform through successful practices in Zhejiang Shuren University.
\end{abstract}

\section{Introduction}

There has been a rapid development in the global outsourcing market. According to IDC statistics, the total size of the global software and outsourcing market is about $\$ 12,215$ billion in 2011.The growth of global offshore outsourcing market is $15 \%-20 \%$. According to the statistics from Department of Commerce, the total amount of China's outsourcing enterprises nationwide undertaking outsourcing contract in 2011 accounted for 23.2\% global share and increased by 6.3 percentage points over the previous year. From research reports, China's domestic outsourcing market is still able to maintain about 15\% to 12\% growth in 2012 and next five years. According to McKinsey's forecast, a gap of 400 thousand qualified personnel will appear in China's development of offshore outsourcing in coming five years.

At present, employees of ITO industry are mainly from university graduates. According to the statistics from Department of Commerce, as the end of 2011, outsourcing enterprises nationwide reached 16,939, with 318.2 million employees, of which 223.2 million have bachelor degrees or above, accounting for $70.1 \%$. The main source of these graduates comes from CSS graduates, while a wide gap existed between their actual knowledge, abilities and qualities, to demands of software outsourcing enterprises. Hence, how to train the talents that adapt to the needs of ITO enterprises and achieve university-enterprises connection (UEC) became a common concern in universities, government and enterprises currently.

In recent years, a number of scholars and computer educators have made some explorations on how to carry out education reform in universities and how to train qualified outsourcing talents. Zheng Xiaorong [1], Xiao Fangming [2] have studied talents training models of outsourcing in higher vocational colleges and courses system reform. Peng Tao, Liu Baomei [4], Zhong Ruicong [5] have paid a lot of efforts on talents training models of outsourcing in undergraduate universities and courses system. In this paper, we analyze contradictions between needs of ITO talents, including knowledge, abilities and qualities, and traditional teaching in CSS. According to the top-level design, and combined with application-oriented undergraduate universities (AOUUs) own characteristics, we propose an ITO talents core competence training (CCT) and UEC-based teaching system design, including a course system and a practical system.

\section{Discussion on Training Plans of ITO Talents}

Talents training objectives oriented as train application-oriented talents for ITO, whom have excellent ITO professional qualities, with sustainable disciplinary knowledge base. They are also 
proficient in the outsourcing language, familiar with outsourcing development, management processes and outsourcing specifications.

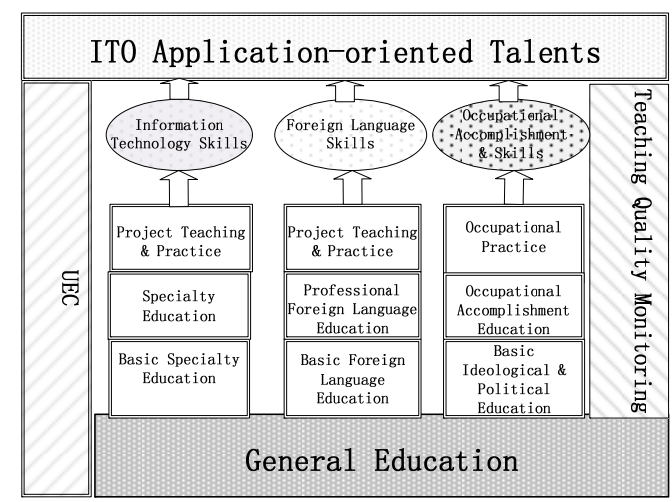

Fig.1. Framework Design

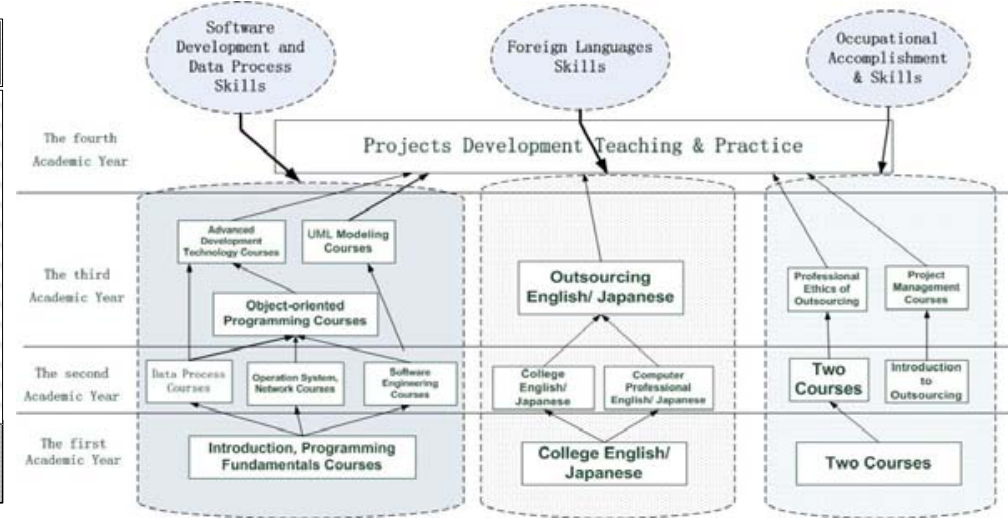

Fig.2. A CCT Courses Group Arrangement

ITO industry require 1-2 years practical experience generally when recruit technical personnel. But traditional undergraduate universities employ an education system as $3.5+0.5$ that students study on-campus for 3.5 years, and are arranged for graduation practice, project and thesis. Students would have only 1-2 months practical experience. To enable graduates have the actual project experience, academic arrangement architecture as $1+2+1$ should be employed. At the first academic year, students take general education. At second and third academic years, they learn specialty foundation, professional basic courses and professional courses. At the last whole year, they participate in project practices in UEC bases or cooperative enterprises, and teaching of graduation period.

\section{Curriculum System and Curriculum Reform}

Through a research on ITO enterprises and IT training institutions, according to demands of knowledge and ability of ITO talents, a revolutionary reconstruction should be carried out on courses groups and curriculum system, which use an organization of disciplines of knowledge traditionally. A CCT courses group arrangement is presented in Figure 2.

There has several ways when design the curriculum system. At first, theoretic lesson hours should be compressed largely, and practical lesson hours should be increased vigorously. In lesson hours' arrangement of traditional teaching of CSS, the ratio of theoretic and practical lesson hours is about 8:2 (including basic common courses). For ITO talents, this proportion is far from enough. The appropriate ratio should be 6.5 : 3.5 or 6: 4,that the proportion should account for $35 \%-40 \%$. Moreover, unnecessary basic common courses and specialties courses should be deleted greatly. the requirements of ITO talents more focus on software development and data process, rather than hardware, so that the unnecessary courses can be ignored. Besides, courses should be arranged on three main lines, foreign language ability, data processing, and software development and testing. The courses related to major professional skills should be organized continuously and progressively. In the aspect of foreign language ability, related courses should be arranged continuously, such as College English or Japanese, Computer Professional English or Japanese, and ITO English or Japanese. About data processing ability, relevant courses are Data Structure, Database, and Database System Development. Considering software development and testing ability, related courses are Programming Fundamentals, Object-oriented Programming, Software Engineering, and so on. To broaden students' horizons and increase students' knowledge, some elective courses should be arranged, such as Computer Information Security, Management Information System, and so on.

Currently, the mainstream development platform in the market is .Net and Java platform. To meet demands of different ITO enterprises and development needs of students' personality, a complete curriculum system can use an architecture as "platforms + modules". Two specialized modules should be set up to carry out teaching separately, which would start at the fifth semester separately, for the students to choose the module and study. 
The curriculum reform and construction should take some skills training as oriented and application courses transformation as means. Firstly, according to the abilities training objectives, teaching objectives of each course can be determined, and then the convergence between various courses in the courses group and teaching focus can be determined subsequently. E.g., for data processing-related courses of information technology like data structures and database, students should be trained to grasp abilities to design database rationally, and process data skillfully. Moreover, universities can construct teaching materials together with enterprises. Besides, teaching methods can have a reform to implement an open, case-based and project-based teaching. Finally, curriculum assessment methods can be reformed with focus on course process, to enhance students' motivation in study.

\section{Practice System and UEC Practices}

Several on-campus and off-campus practice and teaching base have been constructed, and an innovative practice platform has been built, that the practical teaching can be enhanced. A whole process and progressive practice system can be implemented, from curricular experiments, curriculum design, academic research, and holiday post practice, graduate design to UEC strengthened project practice.

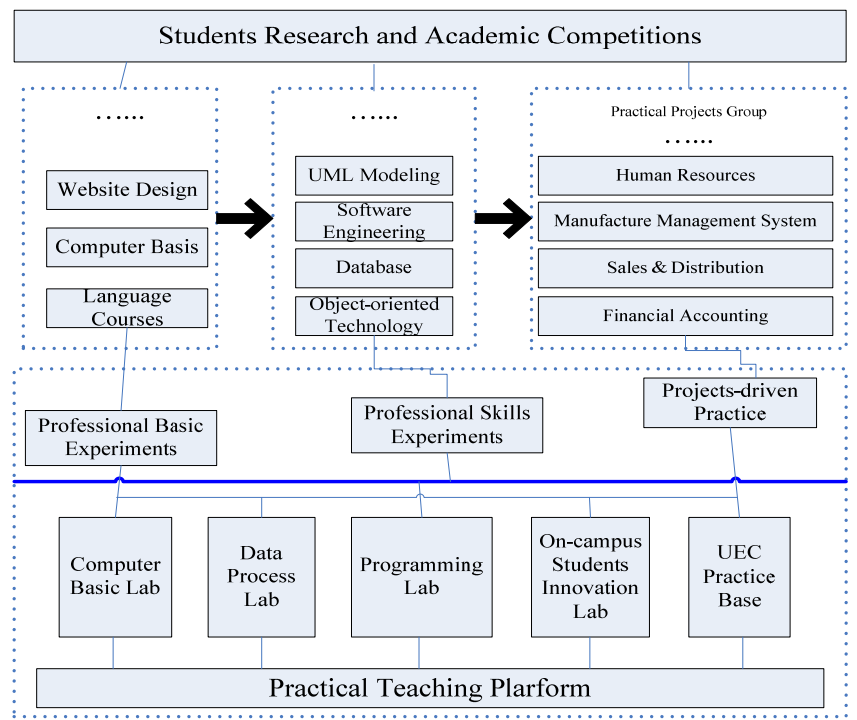

Fig.3. A Practice System

The teaching parts, including curricular experiments, curriculum design should be strengthened. Each main course and professional skills type course should set curricular internships, and the ratio of practice lessons should be no less than $20 \%-30 \%$ of class hours. Each main course should set at least one comprehensive internship. In the design and implementation process of experiments, the UEC model should be introduced in the whole process. The experiment courses group and projects group would be established, to achieve a ladder type abilities-training objective from professional general education, professional skills training, to project comprehensive implementation training. The practice system architecture is shown in Figure 3.

Students are encouraged to participate in the provincial and national computer competitions, to apply for the school and provincial "Science and Technology" projects, to develop their research and innovation capacity, on the basis of students' experiments, and practice and application abilities training.

To improve students' practical ability and increase their experience, carrying out University-Enterprises Cooperation (UEC) with ITO enterprises can be an efficient way. At present, there are several different ways for UEC. Some universities prefer outsourcing all specialty education to enterprises, e.g. IBM Institute. Some universities choose outsourcing enterprises to help train students, such as Tarena. Also some universities select to build up UEC practice base, where Totyu Group is an example. In our opinion, the third method should be more suitable for universities. In this way, the outsourcing talents training-base can be build up by universities and 
enterprises jointly. The practice classes can be set up, and the teaching programs can be developed jointly. In the teaching, the enterprises play a dominant role and the university also participates in. Students would have a 3-5 months post teaching practice before graduation.

\section{Practices in Zhejiang Shuren University}

Zhejiang Shuren University has explored training ITO talents since 2008. The university has re-constructed the training programs taking high-end ITO application-oriented talents as objectives, and made a revolutionary reform on curriculum system and application courses. Several practice bases have been established with some famous software outsourcing enterprises respectively, e.g. Tata Group, Totyu Group, Insigma, and a deep collaboration on both theoretical courses and practical teaching has been carried out. Students can select UEC class in the seventh semester. The university and enterprise would develop a 3-5 months teaching program jointly, and the cooperative teaching content includes professional skills of project development and enterprises culture. After the concentrated study and practice, students would have a 3-5 months post teaching practice in the enterprises' own manufacture projects. In the recent four years, significant results have been achieved on the ITO talents training. Nearly 200 students, from Totyu class, Tata class, Insigma class of UEC, have got high paid jobs in outsourcing enterprises, such as Totyu Group, Tata Group, Insigma, and received full recognition of outsourcing enterprises.

\section{Conclusion}

The ITO industry is a promising industry while short on talent. Traditional software specialty education cannot satisfy the talents requirements of ITO industry, which make it possible that a substantial reform on talents training model and curriculum system. ITO talents training program should be adjusted oriented as skills, knowledge and qualities required by enterprises, and reconstruct curriculum and practice system. While, course objectives and teaching content should be re-determined as abilities decomposition of training objectives, and courses can be constructed by means of application courses transformation, to reform teaching and assessment methods. A deep and omni bearing UEC teaching is an effective way to train ITO talents.

\section{References}

[1] X. Zheng and G. Chen. "A reconstruction on curriculum system promoted by software outsourcing development”. China Adult Education. Vol. 1, pp:149-150, 2010.

[2] F. Xiao. "A conjunction between Outsourcing Industry and Higher Vocational Education”. Academic Forum, Vol.9,pp:144-147, 2010.

[3] T. Peng, Y. Zhang and H. Bao. "Research on Problem Space and Curriculum System of Information Service Specialty” . Journal of Beijing Union University(Natural Sciences). No.2,Vol.24. p61-64.

[4] B. Liu. "Talents Cultivation Program for Software and Information Service Outsourcing Industry”. Computer Education. No.6,2011.

[5] R. Zhong, Y. Xie, and L. Jiang. "Research and Practice on Talents Cultivation Mode of the Software and Information Service Outsourcing”. Science and Technology Management Research. No. 6,2011. p189-193.

[6] S. Ye, C. CHEN and G. Dai. "Research and Practice on Team Building in Teaching IT in Non-governmental Institutions of Higher Learning”. Joural of Zhejiang Shruen University. No.5,2011, p73-77. 